ELORE (ISSN 1456-3010), vol. 18 - 2/2011.

Julkaisija: Suomen Kansantietouden Tutkijain Seura ry.

[http://www.elore.fi/arkisto/2_11/heimo.pdf]

KIRJA-ARVIO

\title{
SOTILAAT TAISTELIVAT, MIEHET MUISTELEVAT
}

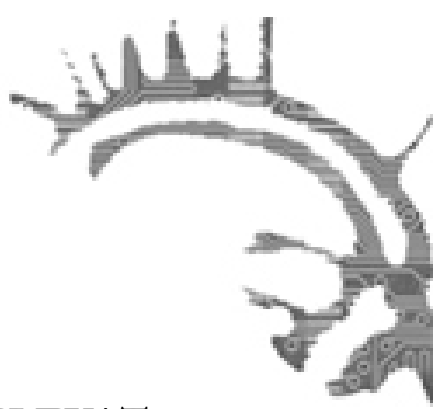

KÕRESAAR, ENE (ed.) 2011: Soldiers of Memory. World War II and Its Aftermath in Estonian Post-Soviet Life Stories. Amsterdam \& New York: Rodopi. 441 sivua.

\section{Anne Heimo}

Soldiers of Memory -teos koostuu kahdeksan virolaisen miehen toista maailmansotaa koskevista muistelmista sekä kahdeksasta tutkimusartikkelista ja johdannosta. Muistelmia tulkitsevat ja analysoivat tutkijat edustavat eri aloja, etnologiaa, folkloristiikkaa, kirjallisuudentutkimusta ja historiaa. Teos on itsenäinen jatko-osa 2004 ilmestyneelle She Who Remembers, Survives: Interpreting Estonian Women's Post-Soviet Life Stories (eds. Kirss \& Kõresaar \& Lauritsin), jossa yhdeksän tutkijaa analysoi yhdeksää NeuvostoVirossa eläneen naisen omaelämäkertaa (ks. Hynninen 2004).

Kirjan toimittaja, etnologi Ene Kõresaar, kertoo, että kirjaan on valittu sellaisia kirjoituksia, jotka kuvastavat yhtäältä mahdollisimman monipuolisesti virolaismiesten sotakokemuksia, mutta toisaalta edustavat sellaisia muistelukohteita, jotka ovat olleet esillä Neuvostoliiton jälkeisessä Virossa. Yksi kirjan omaelämäkerroista perustuu tutkijan vuonna 2008 tekemiin haastatteluihin silloin 85-vuotiaan haastateltavan kanssa. Muut ovat miesten itsensä kirjoittamia, mutta editoituja ja varustettu lähdeviittein. Kirjassa julkaistut kirjoitukset ovat pitkiä, yli 20 -sivuisia, mutta useimmat ovat vain osa samojen miesten kirjoittamia huomattavan laajoja - satoja sivuja pitkiä - omaelämäkertoja, joissa he sodan lisäksi muistelevat elämää Neuvosto-Virossa. Kirjoitukset ovat vuosilta 1989-2005. 1980-luvun lopulla, jo ennen Viron itsenäistymistä vuonna 1991, Viron Kirjallisuusmuseon Kulttuurihistoriallinen arkisto ja Viron Elämäkertayhdistys aloittivat virolaisten omaelämäkertojen keruun. (Ks. Jaago \& Kõresaar \& Rahi-Tamm 2006.) On sanottu, että elämässä pitää olla tapahtunut jotain erityistä, jotta siitä halutaan kirjoittaa. Viron kompleksinen lähimenneisyys on tarjonnut runsaasti aiheita ja kirjoituspyyntöihin on vastattu ahkerasti.

\section{YKSI VAI MONTA SOTAA?}

Aleksander Loog, Heinrich Uustalu, Reinhold Mirk, Boris Jaag, Ailo Ehamaa, Lembitu Varblane, Boris Takk ja Ylo-Vessa Velvelt olivat kaikki nuoria miehiä toisen 
maailmansodan aikana. Sodan syttyessä syyskuussa 1939 vanhin miehistä, Loog, oli 25-vuotias ja nuorin, Velvelt, vasta 13-vuotias. Miesten kokemukset toisen maailmansodan aikana poikkeavat toisistaan hätkähdyttävän paljon. He taistelivat eri maiden joukoissa (Neuvostoliiton, Saksan ja Suomen) ja eri rintamilla. Heillä ei ollut edes yhteistä vihollista, ja sekin saattoi vaihtua sodan kestäessä. Miehet kirjoittavat hyvinkin yksityiskohtaisesti monenkirjavista kokemuksistaan ja tapaamistaan ihmisistä. Näissä muistelmissa ei pysähdytä pitkäksi aikaan yhteenkään paikkaan, vaan miehet tuntuvat olevan jatkuvasti liikkeellä, töissä ja vapaalla, koulutus- ja sotilastehtävissä, vangittuina ja paossa. Jatkuvan liikkeelläolon on todettu edesauttavan sotatapahtumien muistamista (Rosenthal 1991). Yhteistä miehille oli se, että koska he kokivat olevansa ensisijaisesti virolaisia, heillä oli vaikeuksia löytää mieltä osallistumiselle sotaan vieraissa joukoissa. Isänmaan puolesta voi kuolla mutta ei vieraan miehittäjän.

Kirjoitukset ovat ennen kaikkea kertomuksia selviytymisestä. Eivätkä nämä miehet selviytyneet vain kerran vaan lukuisia kertoja milloin Neuvosto-armeijan, milloin saksalaisten käsistä. Osa joutui karkotetuksi Siperiaan sodan jälkeen ja pääsi palamaan vasta 1950-luvulla Viroon. Kirjoituksissaan miehet pohtivat selviytymistään. Osa näkee pelastuneensa onnen tai kohtalon avulla, osa oman neuvokkuutensa ansiosta. Selviytyminen vaati myös riskinottokykyä, neuvottelutaitoja, huijaamista, valehtelua, varastelua, identiteetin ja puolen vaihtoa ja runsain määrin rohkeutta ja uskoa selviytymiseen. Osa miesten tekemistä valinnoista oli tietoisia ja suunniteltuja, osa ei. Koska kyse on selviytyjien tarinoista, on selvää, että kirjoittajat pystyivät näkemään aikanaan huonolta valinnalta vaikuttaneessa tilanteessa jälkikäteen myös myönteisiä puolia.

Miesten kirjoituksia lukee antaumuksella, sillä ne ovat tunnelmaltaan pikemmin jännittäviä ja kiehtovia kuin surullisia tai raakoja. Kirjoitukset muistuttavat suuresti Gabriele Rosenthalin (1991) haastattelemien saksalaissotilaiden toisen maailmansodan aikaisia omaelämäkerrallisia kuvauksia. Sen sijaan, että saksalaissotilaat olisivat käsitelleet kipeitä muistojaan, he rakensivat sotakokemuksistaan laajoja monipolvisia kertomuksia, joissa he selostivat seikkaperäisesti saapumisiaan ja lähtöjään sekä kuvasivat itseään nokkelina ja rohkeina sotilaina. Rosenthalin mukaan ero ensimmäisessä ja toisessa maailmansodassa taistelleiden miesten muistelmissa on suuri. Ensimmäisessä maailmansodassa taistelleiden oli vaikea kertoa sotakokemuksistaan, koska niitä ei pystytty jäsentämään kertomuksiksi. Ensimmäinen maailmansota oli asemasota, joka käytiin taisteluhaudoissa. Rosenthalin mukaan tämä vaikutti siihen, että sotilaiden oli vaikea kiinnittää muistojaan mihinkään tiettyyn tapahtumaan tai paikkaan. Se oli myös luonteeltaan myöhempää sotaa traumaattisempi, koska juoksuhaudoissa sotilaat joutuivat olemaan jatkuvasti kuoleman kanssa tekemisissä.

\section{SOTAMUISTOJEN KIELIOPPI}

Toisen maailmansodan tulkintoja on tarkasteltu myös Aristoteleen runousopin mukaan eepoksina, tragedioina ja komedioina. Pääosa kansallisista sotatulkinnoista on joko eeppisiä kertomuksia maan sankarillisista uroteoista tai traagisia uhrikuvauksia. Näiden ongelma on se, että ne kilpailevat keskenään, toisen voitto on toisen häviö, ja 
johtavat näin ollen helposti historia- ja muistisotiin, kuten Baltian maiden ja Venäjän välillä. Marko Lehti, Matti Jutila and Markku Jokisipilä (2008) ehdottavat ratkaisuksi komediaa. Komedia on luonteeltaan humoristinen, se sisältää hullunkurisia juonenkäänteitä ja päättyy useimmiten onnellisesti. Komedia tarjoaisi mahdollisuuden käsitellä sotaa vaihtoehtoisella tavalla kyseenalaistamalla jaon sodan voittajiin ja häviäjiin sekä hyviin ja pahoihin esittelemällä poikkeuksellisia tekoja ja henkilöitä. Mielestäni Soldiers on Memory -teoksen sotamuistelmat edustavat nimenomaan komediaa. Muistelmia ei voi kuvata humoristisiksi eikä kevyiksi, mutta niistä löytyy vastaavia piirteitä kuin Jaroslav Hašekin (1923/2002) romaanista Kunnon sotamies Švejk, jossa seurataan veijarimaisen päähenkilön Švejkin matkaa ensimmäisen maailmansodan pyörteissä. Myös muistelijat kohtaavat monenlaisia henkilöitä ja joutuvat mitä kummallisimpiin tilanteisiin. Samalla he tulevat kuvanneeksi toisen maailmansodan kompleksisuutta Virossa, jossa perheenjäsenet saattoivat olla eri puolilla, mutta myös yksi ja sama henkilö saattoi sodan aikana vaihtaa puolta.

Teos on kiinnostava ja asiantunteva mutta laajuudessaan haastava lukukokemus varsinkin tutkimusartikkelien osalta. Kukin tutkija on valinnut oman näkökulman analyysinsa lähtökohdaksi, esimerkiksi kertojien syyt muistelemiselle (Aarelaid-Tart ja Hinrikus) tai sotamuistojen suhde kirjoittajan omaelämäkertaan (Jaago ja Kõresaar). Tästä huolimatta on artikkeleita vaikea erottaa toisistaan, koska niissä kaikissa käsitellään muistojen rakentumista ja yksityisen ja julkisen muistamisen suhdetta. Kussakin artikkeleissa tarkastellaan, mitä kirjoittaja on muistellut, mistä vaiennut sekä miten hän on tiettyjä kokemuksiaan kuvannut. Lisäksi pohditaan, millä tavoin julkinen historia - muun muassa julkinen keskustelu, kaunokirjallisuus ja muistelmat - näkyvät niissä. On selvää, että miesten sota-aikaiset kokemukset poikkesivat toisistaan mutta sitä, missä määrin heidän tapansa muistella kokemuksiaan suhteessa muihin vastaavassa tilanteessa olleisiin, on lukijan hankala todeta. Onko syy kirjan rakenteessa, jossa yksi tutkija keskittyy yhteen kirjoittajaan vertailematta kirjoitusta muihin muistelmiin vai tutkijoiden edustamassa muistitutkimuksen suuntauksessa?

\section{YHTEISTÄ JA JAETTUA}

Kaikki tutkijat ovat tunnettuja omaelämäkerrallisten aineistojen asiantuntijoita. He edustavat eri aloja, mutta nojaavat kaikki kulttuuriseksi muistitutkimukseksi kutsuttuun muistitutkimuksen suuntaukseen, joka on saanut myös Suomessa jalansijaa etenkin historiantutkijoiden keskuudessa (ks. esim. Grönholm 2010). Suuntaus perustuu erityisesti egyptologien Jan ja Aleida Assmannin ja Maurice Halbwachsin näkemyksiin kollektiivisesta muistista, joka yhdistää kansakuntia ja ryhmiä, ja joka välittyy julkisen historian avulla. Muistitietotutkija Alessandro Portelli (ks. esim. 1997, 140-160) on useaan kertaan huomauttanut käsitteeseen sisältyvästä harhasta, että jokin kokemus tai tapahtuma - tässä tapauksessa toinen maailmansota - synnyttäisi ybteisen muiston (shared memory) yhteisössä. Portelli puhuu tästä syystä itse mieluiten jaetusta muistista (divided memory), jolla hän haluaa kiinnittää huomiota kokemusten erilaisiin, toisistaan poikkeaviin, tulkintoihin, siihen että ihmiset eivät koe asioita samalla tavoin. 
Tulkintaeroihin kirjassa toki puututaan, mutta kulttuurisessa muistitutkimuksessa kollektiivinen muisti on se, jonka katsotaan ohjaavan ja vaikuttavan yksilölliseen muistiin. Sitä vastoin (Portellin edustamassa) muistitietotutkimuksessa nähdään, että kysymys on molempiin suuntiin vaikuttavasta prosessista ja yksilö on ensisijainen muistelija (Abrams 2010, 99-103).

Syyskuussa 2011 Turussa järjestettiin historiatieteiden kansainvälinen symposium Shared Past-Conflicting Histories, jonka aikana pohdittiin kansallisten sotahistorioiden tarvetta ja tulevaisuutta. Seminaarissa esitettiin, että jatkossa kollektiivisten sotahistorioiden sijasta olisi keskityttävä yksilöihin ja heidän kokemuksiinsa. Soldiers of Memory on tässä mielessä mitä ajankohtaisin teos. Olisiko seuraava askel kokoelma, jossa eri maiden sotilaat muistelisivat samaa sotaa rintaman eri puolilla?

\section{KirjallisuUs}

ABRAMS, LYNN 2010: Oral History Theory. London \& New York: Routledge.

GRÖNHOLM, PERTTI 2010: Muistomerkkejä ja kolaroivia kertomuksia. Vuoden 2007 pronssisoturikiista ja yhteisöjen kulttuuriset työkalut. - Grönholm, Pertti \& Sivula, Anna (toim.), Medeiasta pronssisoturiin. Kuka tekee menneestä historiaa? Turku: Turun Historiallinen Yhdistys ry.

HAŠEK, JAROSLAV 2002: Kunnon sotamies Švejk maailmansodassa. Suomentanut Eero Balk. Kuvitus: Josef Lada. 5. painos. Helsinki: Tammi.[1991]

HYNNINEN, ANNA 2004: Neuvostovallan jättämät jäljet. Itsenäisen Viron naiset elämänsä kirjoittajina. - Elore 2. [Online] <http://www.elore.fi/arkisto/2_04/ hyn204a.html> [19.10.2011.]

JAAGO, TIIU \& KÕRESAAR, ENE \& RAHI-TAMM, AIGI 2006: Oral history and Life Stories as a Reserach Area in Estonian History, Folkloristics and Ethnology. - Elore 1. [Online] < http://www.elore.fi/arkisto/1_06/jkr1_06.pdf > [19.10.2011.]

KRISS, TIINA \& KÕRESAAR, ENE \& LAURISTIN, MARJU (eds.) 2004: She Who Remembers Survives. Interpreting Estonian Women's Post-Soviet Life Stories. Tartu: Tartu University Press.

LEHTI, MARKO \& JUTILA, MATTI \& JOKISIPILÄ, MARKKU 2008: NeverEnding Second World War. Public Performances of National Dignity and the Drama of the Bronze Soldier. - Journal of Baltic Studies 39(4). [Online] < http:/ / www.tandfonline.com/doi/full/10.1080/01629770802461175> [19.10.2011.]

PORTELLI, ALESSANDRO 2007: The Battle of Valle Giulia. Oral History and the Art of Dialogue. Madison: The University of Wisconsin Press.

ROSENTHAL, GABRIEL 1991: German War Memories: Narrability and the Biographical and Social Functions of Remembering. - Oral History 19(2).

Filosofian tohtori Anne Heimo toimii Suomen Akatemian tutkijatohtorina Turun yliopiston historian, kulttuurin ja taiteiden tutkimuksen laitoksella. 